\title{
Expert System Untuk Acupressure Dengan Metode Backward Chaining
}

\author{
Ratih Purwasih \\ Universitas Putra Indonesia "YPTK" Padang \\ Email: ratihpurwasih@upiyptk.ac.id
}

\begin{abstract}
Acupressure or in other words called reflexology is a way of treating the disease through nerve center points associated with certain organs. In other words, healing is a disease through nerve massage to improve blood circulation. With the design of an expert acupressure system using foot massage created to help detect health problems experienced by someone by providing therapeutic solutions using foot reflexology in the form of graphics that must be massaged by the user without having to wait for help from people who are experts in their fields. The design of this system uses Backward Chaining inference, with the implementation of the system using the MySQL database system and Visual Basic program. From the system design that is made, it can be obtained a point massage solution that must be treated based on the symptoms felt.
\end{abstract}

Keywords: Expert System, Backward Chaining, Efect

\begin{abstract}
Abstrak
Acupressure atau dengan kata lain disebut pijat refleksi adalah suatu cara pengobatan penyakit melalui titik pusat urat syaraf yang berhubungan dengan organ-organ tertentu.dengan kata lain adalah penyembuhan penyakit melalui pijat urat syaraf untuk memperlancar peredaran darah.Dengan rancangan sistem pakar acupressure dengan menggunakan pijatan dikaki dibuat untuk membantu mendeteksi gangguan kesehatan yang dialami oleh seseorang dengan memberikan solusi terapi dengan menggunakan pijat refleksi kaki berupa grafis yang harus dipijat oleh pengguna tanpa harus menunggu bantuan dari orang yang ahli dibidangnya. Rancangan sistem ini menggunakan inferensi Backward Chaining, dengan implementasi sistem menggunakan sistem database MySQL dan program Visual Basic. Dari rancangan sistem yang dibuat maka dapat diperoleh solusi titik pijat yang harus diterapi berdasarkan gejala yang dirasakan.
\end{abstract}

Kata kunci: Sistem Pakar, Backward chaining, Gejala

\section{Pendahuluan}

Kemajuan teknologi komputer pada saat sekarang ini dapat membantu kehidupan manusia bahkan di luar disiplin ilmu komputer sekalipun. Salah satunya adalah program sistem pakar,yang mana sistem pakar ini dapat membantu orang awam mengerjakan pekerjaan para ahli, melakukan proses secara berulang secara otomatis, menyimpan pengetahuan dan keahlian para pakar mampu mengambil dan melestarikan keahlian para pakar (terutama yang termasuk keahlian langka), mampu beroperasi dalam lingkungan yang berbahaya. Memiliki kemampuan untuk bekerja dengan informasi yang tidak lengkap dan mengandung ketidakpastian. Pengguna bisa merespon dengan jawaban 'tidak tahu' atau 'tidak yakin' pada satu atau lebih pertanyaan selama konsultasi dan sistem pakar tetap akan memberikan jawaban, Program ini bertindak sebagai konsultan yang cerdas atau penasihat dalam suatu lingkungan keahlian tertentu, sebagai hasil himpunan pengetahuan yang telah dikumpulkan dari beberapa orang pakar.

Acupressure merupakan bagian dari pengobatan tradisional yang berasal dari negeri tiongkok Cina. Di Indonesia Acupressure lebih dikenal dengan Pijat refleksi, Ketika kita membicarakan mengenai refleksi ini tentunya yang terbayang dalam benak kita adalah hal yang berkaitan dengan pijat pada daerah kaki. Karena memang pijat ini identik dengan refleksi kaki. Dan begitu banyak pula manfaat pijat refleksi ini bagi kesehatan badan kita, Karena, manfaat pijat langsung dirasakan. Selain itu, pijat refleksi juga bisa membantu menghilangkan depresi dan penyakitpenyakit lainnya ( Assyarif : 2011 ).

Jenis penyakit pada manusia terdiri dari berbagai Macam-macam penyakit. Banyak masyarakat yang kurang pengetahuan tentang acupresure yang terbukti dapat membantu dalam penyembuhan berbagai jenis penyakit. Pemijatan ini memberikan Informasi tentang titik-titik pijat yang mana harus dipijat. Oleh karena itu, dibutuhkan suatu aplikasi yang dapat membantu untuk mendiagnosa dan penyembuhan penyakit yang diderita oleh pasien tersebut dengan menggunakan Pemijatan yaitu sistem pakar. Dengan memberikan suatu pertanyaan dan informasi dari sistem pakar, user memperoleh kesimpulan yang sesuai dengan cepat sehingga dapat menghemat biaya dan waktu. Pengetahuan-pengetahuan yang dimiliki oleh seorang pakar Pijat Refleksi disimpan di dalam program komputer. Dengan adanya sistem pakar dengan metode backward chaining, diharapkan dapat membantu masyarakat awam dalam menentukan titik-titik pijat pada telapak.. 


\section{Metode Penelitian}

Sistem pakar terdiri dari dua bagian utama, yaitu lingkungan pengembangan (development environment) dan lingkungan konsultasi (consultation environment). Development Environment dipakai oleh pembangun sistem pakar untuk membangun komponen-komponen dan mengenalkan suatu pengetahuan kepada knowledge base. Consultation Environment dipakai oleh user untuk mendapatkan suatu pengetahuan yang berhubungan dengan suatu keahlian [1].

\section{LINGKUNGAN KONSULTASI LINGKUNGAN PENGEMBANGAN}

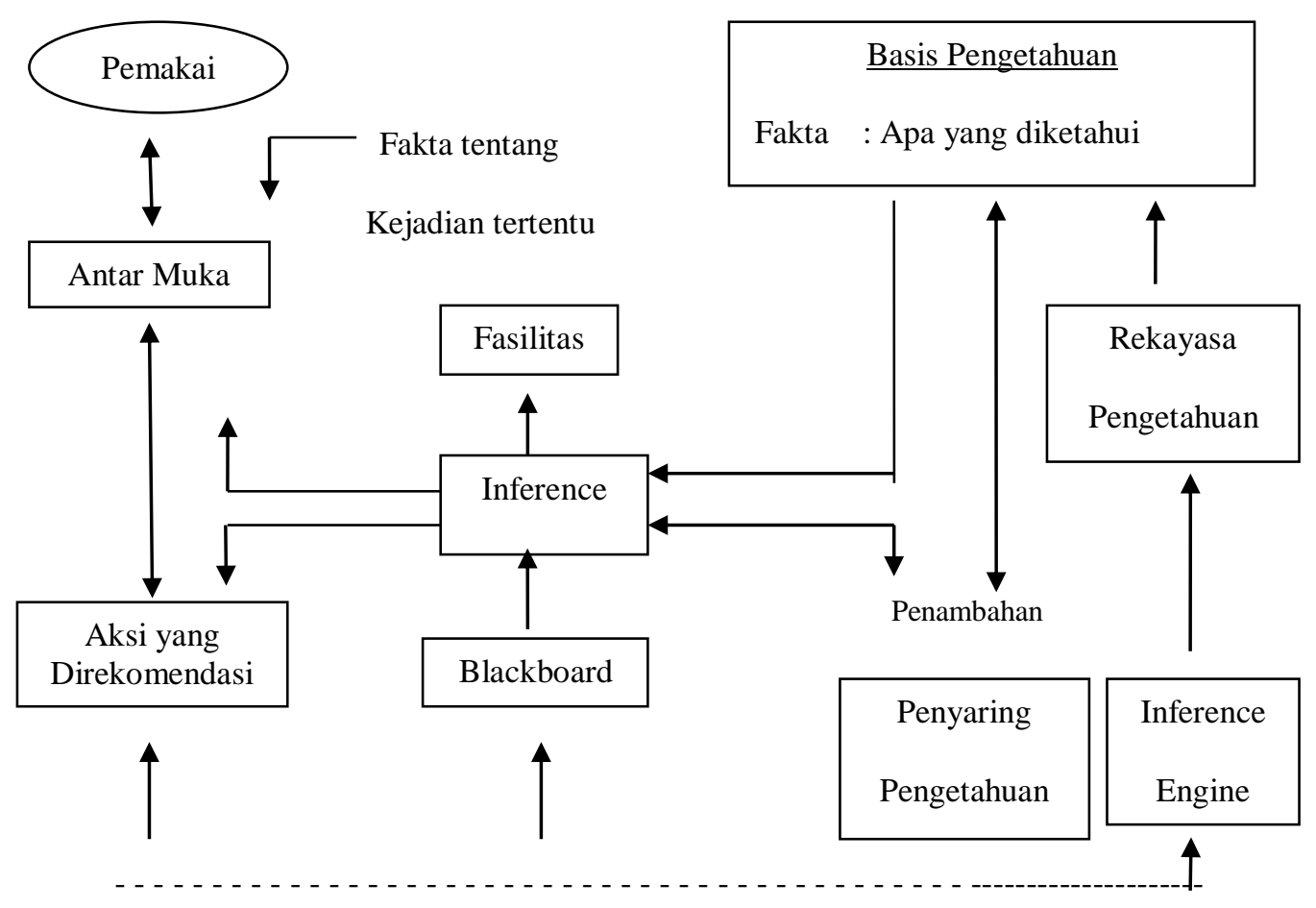

Pengetahuan

\section{Gambar 1 Struktur Sistem Pakar}

Pijat refleksi merupakan bagian dari pengobatan tradisional yang berasal dari negeri Tiongkok Cina. Ketika kita membicarakan mengenai refleksi ini tentunya yang terbayang dalam benak kita adalah hal yang berkaitan dengan pijat pada daerah telapak kaki. Karena memang pijat ini identik dengan refleksi kaki. Dan begitu banyak pula manfaat pijat refleksi ini bagi kesehatan badan kita, Karena, manfaat pijat langsung dirasakan. Selain itu, pijat refleksi juga bisa membantu menghilangkan depresi dan penyakit-penyakit emosi lainnya. Buktinya, kaum wanita di Inggris beberapa tahun belakangan mulai banyak mendalami ilmu pijat ini. Berdasarkan studi yang dilakukan oleh International Journal of Alternative and Complementary Medicine pada November 1996, para wanita yang menderita stres dan depresi merasa ada perbaikan setelah menjalani terapi pijat refleksi selama 30 menit setiap minggu [2].

Titik-titik refleksi pada kaki tersebar di seluruh bagian kaki. Ada yang di bagian bawah (telapak kaki), punggung kaki, dan bagian samping kaki. Titik refleksi pada kaki kanan dan kaki kiri semua berhubungan dengan sistem peredaran darah yang mengalir pada organ-organ tubuh.

1. Titik Refleksi Pada Kaki Bagian Bawah (Telapak)

Titik-titik refleksi pada telapak kaki berhubungan dengan seluruh organ tubuh. Titik-titik refleksi dibagi menjadi bagian bawah jari-jari, telapak bagian depan, telapak bagian tengah, dan telapak bagian belakang. 
a. Titik refleksi pada bagian bawah jari-jari kaki berhubungan dengan organ otak, dahi, hidung, leher, mata, dan telinga.

b. Titik refleksi pada telapak bagian depan berhubungan dengan bahu, pundak (otot trapezius), kelenjar tiroid, kelenjar paratiroid, dan paru-paru.

c. Titik refleksi pada telapak bagian tengah berhubungan dengan lambung, usus 12 jari, pankreas, kelenjar adrenalin, ginjal, jantung, usus besar, dan limpa.

Titik refleksi pada telapak bagian belakang berhubungan dengan ureter (saluran kencing), usus kecil, kandung kemih, rektum, anus, lutut, insomnia, dan kelejar reproduksi[3].
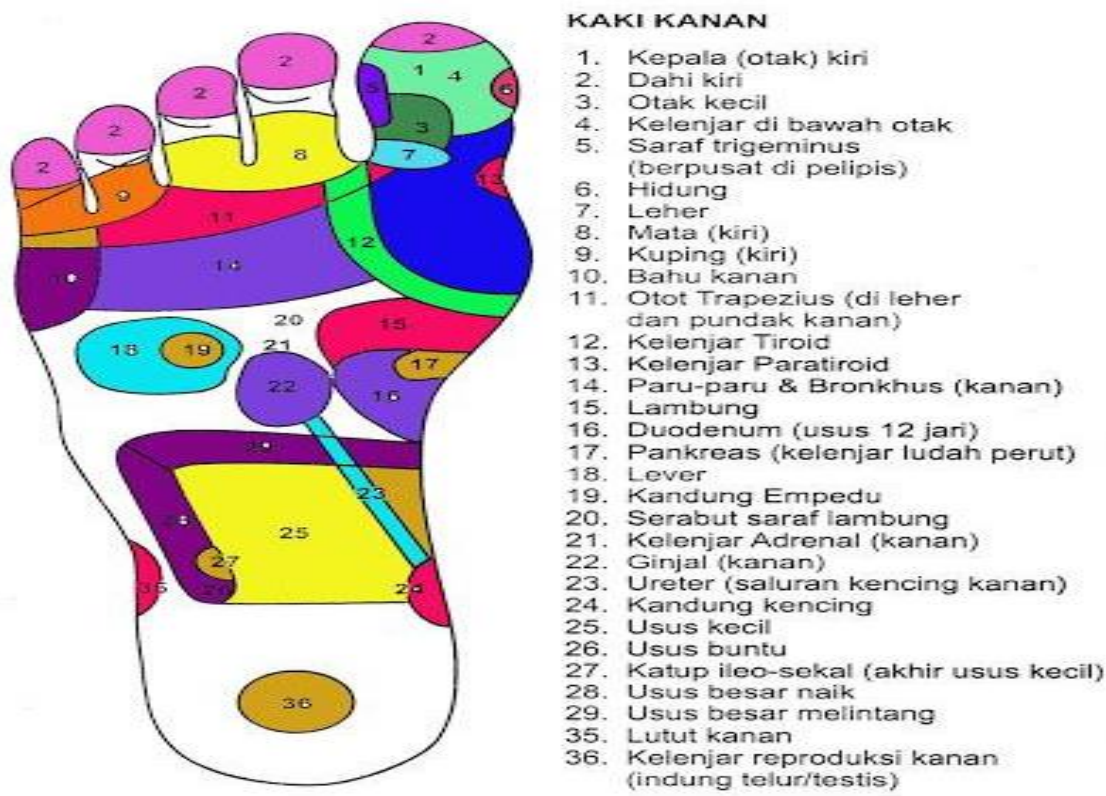

Gambar 2 Daerah Titik Pijat Telapak kaki kanan
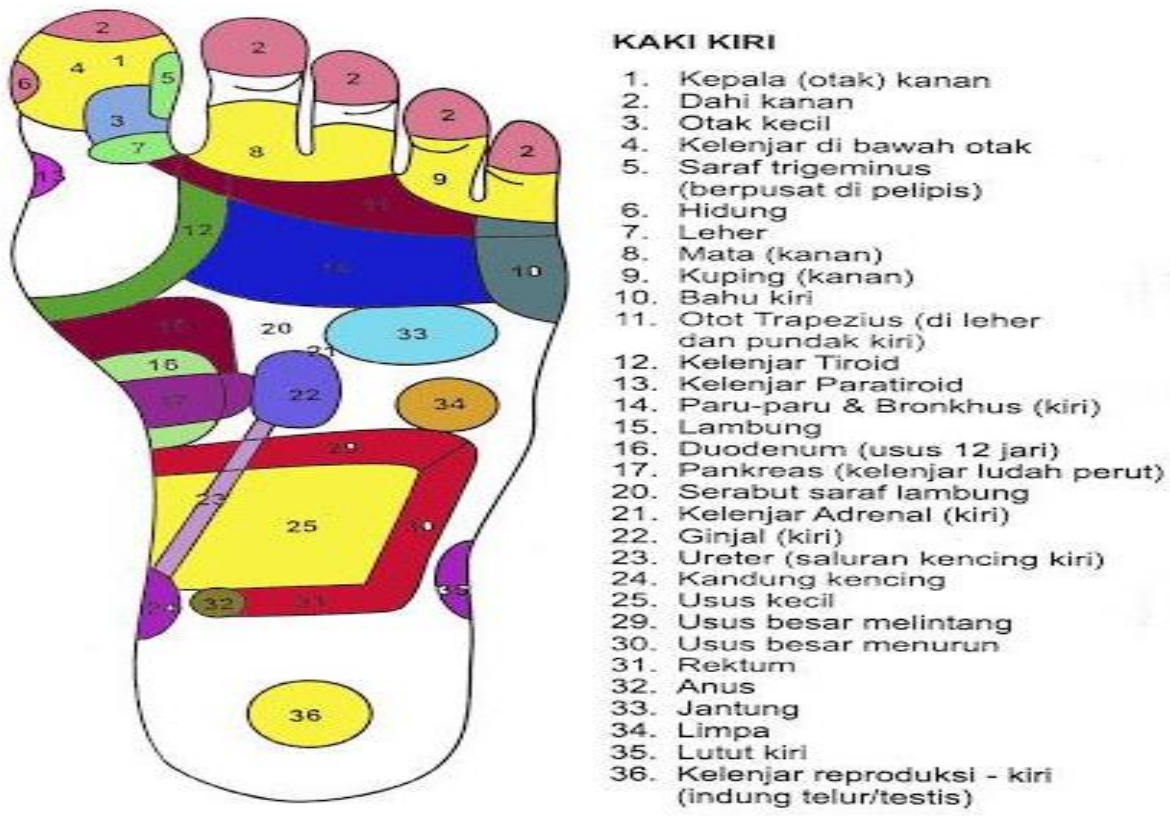

\section{Gambar 3 Daerah Titik Pijat Telapak kaki kiri}

Jurnal Teknologi Vol 9 No 2 (2019) 31-36 


\section{Hasil dan Pembahasan}

Form ini berfungsi untuk konsultasi user/pasien dan sistem, pertama form dijalankan maka user/pasien harus memilih hipotesis awal dari titik pijat yang akan dilakukan, seperti contoh di bawah ini, titik pemijatan yang dilakukan yaitu pada area 3, 17, 18, 19, 20, 22a, 23, 24, maka akan tampil daftar kondisi/gejala dari titik pijat tersebut, kemudian user/pasien memilihkondisi/gejala yang dirasakan, setelah memilih kemudian tekan tombol proses untuk melihat hasil diagnosis yang diberikan oleh sistem. Mesin inferensi akan mencocokkan antara kondisi/gejala yang tersedia di dalam database dengan kondisi/gejala yang dirasakan olehuser/pasien, jika memenuhi rule-1, maka ditampilkanlah hasil diagnosis dan penjelasan dari hasil diagnosis

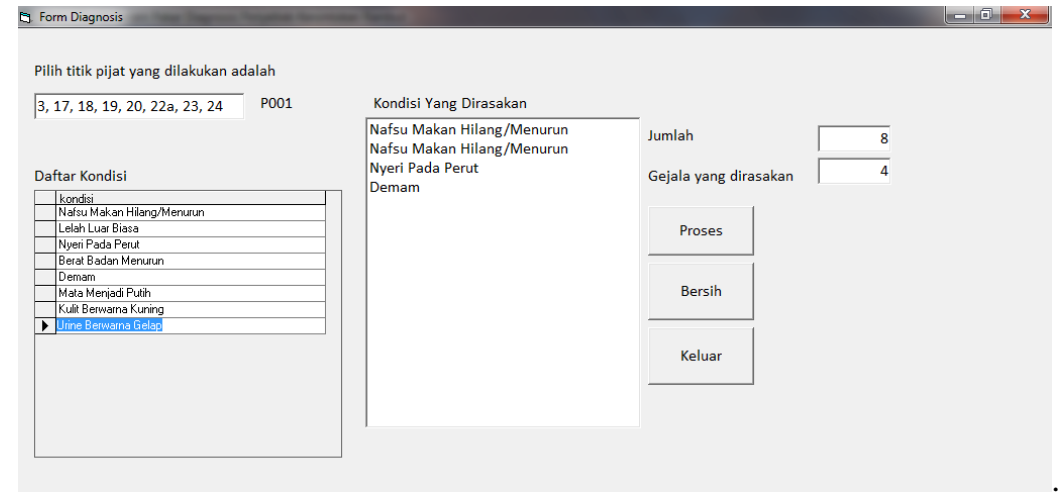

Gambar 4. Form Konsultasi Area PijatAccupresure

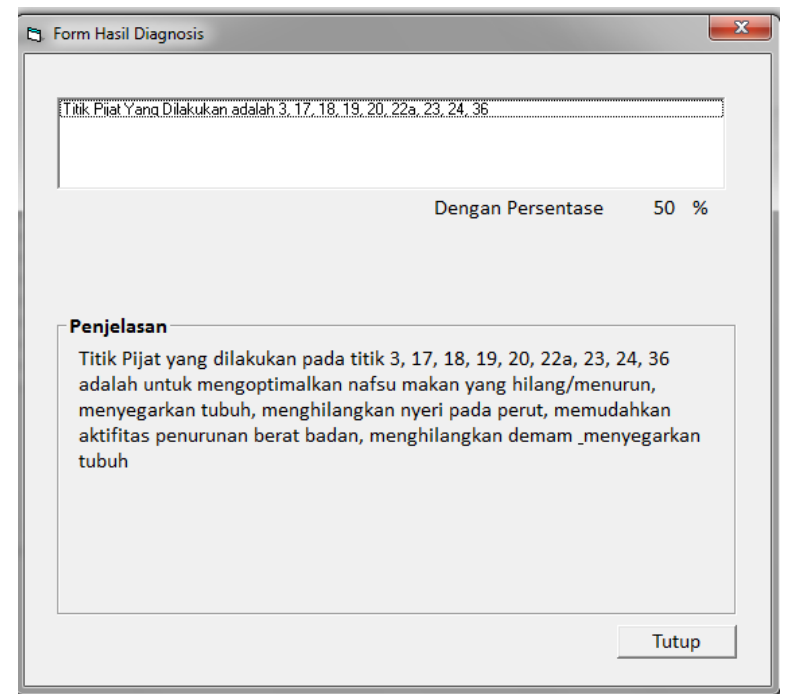

Gambar 5. Hasil Diagnosis untuk area pijat (acupressure)

Berikut ini adalah pengujian rule untuk titik pijat 12, 14a, 13, dan 12a, maka tampi ldaftar kondisi/gejala yang tersedia di dalam database, user/pasien memilih kondisi/gejala yang dirasakan 


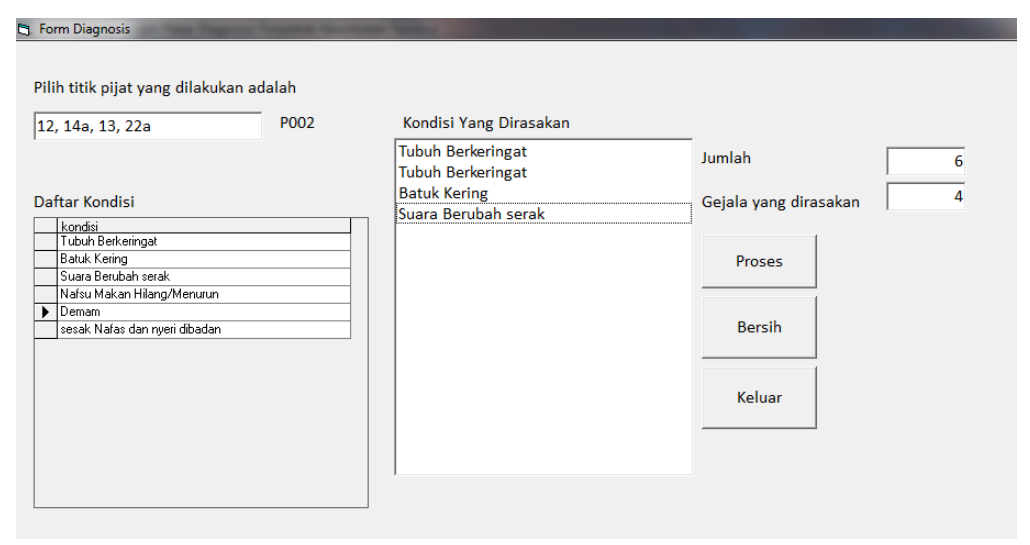

Gambar 6. Form untuk titik 12, 14a, 13, dan 12a

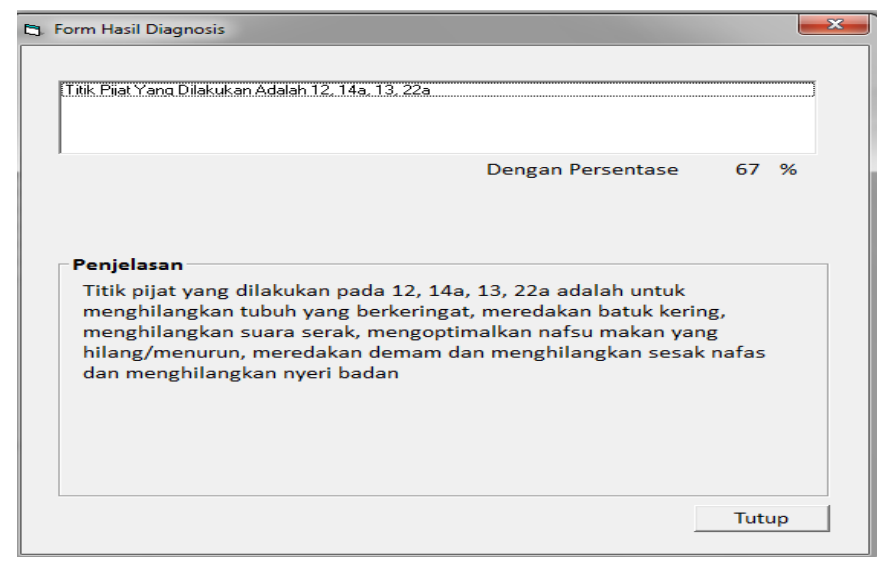

Gambar 7. Hasil Diagnosis untuk titik 12, 14a, 13, dan 12a

\section{Kesimpulan} berikut :

berdasarkan penelitian dan pembahasan yang dilakukan, maka dapat disimpulkan beberapa hal sebagai

1. Sistem pakar yang dibangun adalah untuk menentukan titik pemijatan pada telapak kaki sesuai dengan gejala yang dirasakan oleh user, kemudian menerapkannya ke dalam rule yang masingmasing merepresentasikan titik pijat.

2. Metode Backward chaining bisa digunakan untuk melakukan penelusuran untuk menentukan titik pemijatan.

\subsection{Saran}

Sebagai akhir dari penelitian ini, kami ingin menyampaikan saran-saran yang mungkin bermanfaat bagi siapa saja yang berminat untuk menggunakan sistem ini

1. Diharapkan dengan dikembangkan sistem pakar ini, jenis gejala yang diinputkan agar lebih banyak lagi, sehingga lebih memudahkan untuk menentukan titik Pijat pada telapak kaki.

2. Rancangan sistem pakar untuk menentukan titik Pijat pada telapak kaki ini, penulis rasakan masih jauh dari kesempurnaan, untuk itu penulis mengharapkan ada pihak atau peneliti lain yang mau mengembangkan dan melanjutkan penelitian ini. 
Untuk mendapatkan hasil prediksi yang lebih akurat dan lebih mendekati kebenaran sebaiknya diterapkan metodemetode statistik atau metode sistem pengambilan keputusan lainnya.

\section{Daftar Rujukan}

[1] Asyarif (2011),"Pijat Refleksi”. http://pijatpaksyarif.blogspot.com.

[2] Agus Madani (2010), "Manfaat Pemijatan", http://refleksiology.blogspot.com.

[3] Gangsar R. Hayuaji (2013), "Jago Pijat Refleksi Tanpa Guru", Flashbook, Jakarta Selatan

[4] Kusrini (2006), "Sistem Pakar Teori Dan Aplikasi”, Andi, Yogyakarta.

[5] Mark S, “Kesembuhan Melalui Pijat Refleksi:, Mawar, Surabaya.

[6] Sri Hartati \& Sari Iswanti (2008), "Sistem Pakar \& Pengembangannya", Graha Ilmu, Yogyakarta.

[7] Yudanti Astriati (2013), “"Macam-macam Penyakit yang dapat diatasi dengan Pijat Refleksi”, http://yudantiastriati.wordpress.com 